\title{
KAJIAN SEMANTIK PROTOTIPE TERHADAP ISTILAH “DESA WISATA”
}

\author{
Ari Wulandari \\ Email: kinoysan@gmail.com \\ Fakultas Ilmu Budaya, Universitas Gadjah Mada, Yogyakarta
}

\begin{abstract}
Every person has a specific idea of a word, term, phrase, or discourse. The thought is heavily influenced by culture background and surrounding. This study uses the term "tourist village" to understand the thinking of society. The objectives of this study are to assess and describe the prototype semantics "tourist village" based on the notion of society.The study was conducted using a questionnaire that has been designed based on the hypothesis derived from field observations regarding the definition of "tourist village". The questionnaire has given to 50 persons at random. The respondents answer was counted, and the results were analyzed based on the predetermined variables. The research proves that prototype semantics "tourist village" as linguistics study has four main variables, namely the beauty of nature, people skills, culture, and the arrival of people. The results of this study concluded that the prototype semantics "tourist village" according to the community is a village that has a natural beauty, people skills are adequate and special, unique culture, and there are people who want to know the arrival of distinctiveness that is owned in the village.
\end{abstract}

Key words: culture, linguistics, natural beauty, people skills, prototype semantics, the arrival of people, tourist village 


\section{PENGANTAR}

\section{Latar Belakang}

Desa Wisata (DW) adalah istilah yang cukup popular di tahun 2019 hingga sekarang ini. Istilah ini menjadi semacam primadona baru di kalangan warga desa dan seluruh pihak yang terkait dengan keberadaan desa. Hal ini terjadi karena adanya program pemberdayaan desa untuk menjadi DW dengan memanfaatkan potensi di setiap desa. Namun demikian, tidak setiap desa dapat serta-merta menjadi DW. Ada unsur-unsur tertentu yang harus dipenuhi untuk menjadikan suatu desa sebagai DW. Pun demikian, tidak setiap warga desa menyadari dan memahami pengertian atau definisi DW. Itulah sebabnya perlu dilakukan riset tentang pengertian DW secara lebih menyeluruh. Bukan sekedar kata "desa" dan "wisata" yang diberi pengertian terpisah dalam KBBI (2007:256). Dalam KBBI online terbaru (kkbi.web.id) diakses Desember 2019, istilah DW juga belum termasuk istilah yang diterangkan sebagai satu kesatuan istilah, tetapi dua istilah, yaitu "desa" dan "wisata".

Istilah DW yang akan dikaji dan dideskripsikan dalam penelitian ini merupakan satu istilah dengan kategori abstrak dan bertingkat. Pengertian DW tidaklah tepat kalau dimaknai hanya dengan desa sebagai tujuan atau tempat wisata. DW merupakan istilah baru dalam khazanah perbendaharaan kosakata bahasa Indonesia. Istilah ini muncul seiring dengan adanya program pemerintah Indonesia untuk mengangkat seluruh potensi desa dengan prinsip pemberdayaan masyarakat.

Pada mulanya konsep DW ini terkenal dengan istilah "desa kunjungan wisata" yang menjadi program resmi pemerintah untuk peningkatan kunjungan wisatawan ke Indonesia pada tahun 1992. Selanjutnya, sekitar tahun 2000-an istilah "desa kunjungan wisata" itu menjadi istilah DW yang lebih pendek dan dianggap lebih praktis. Istilah DW inilah yang kemudian menjadi populer di kalangan masyarakat.

Program DW terus digalakkan hingga sekarang dan Kementerian Pariwisata dalam rilis online bisnis.com tanggal 15 Juli 2019 menargetkan Indonesia dapat memiliki 2000 DW hingga akhir tahun ini (2019). Hal ini untuk meningkatkan potensi pariwisata setiap desa dan meningkatkan pendapatan asli daerah (PAD). Terlebih dengan adanya program otonomi daerah, maka pengelolaan dan pengembangan DW ini hampir mutlak menjadi kewenangan dan otoritas pemerintah daerah. Setiap daerah dengan pihak terkait berhak menjadikan wilayahnya sebagai DW dengan memanfaatkan segala potensi dan sumber daya yang ada di wilayah tersebut.

Dalam pemikiran masyarakat secara luas, sangatlah mungkin setiap orang mengetahui arti atau maksud DW. Secara umum, mereka masih mendefinisikan DW sebagai desa untuk tujuan atau tempat wisata. Sebagian lagi memberikan definisi DW sebagai tempat yang indah, untuk wisata kuliner, tempat beli kerajinan, dll. Pengertian DW bagi tiap orang ternyata berbeda-beda.

Hal ini menjadi sangat menarik karena sebagian besar orang menganggap DW adalah desa yang indah dan sering dikunjungi. Tentu saja pengertian DW dalam kajian fenomenologi ini tidak sesederhana itu. Pada kenyataannya yang dimaksud DW di Indonesia sangatlah beragam; ada DW dengan keindahan alam, ada DW 
dengan kerajinan masyarakat, ada DW dengan homestay yang unik, ada DW dengan keunikan yang khas, dll.

Definisi istilah DW inilah yang akan diangkat dan dideskripsikan dalam artikel ini. Itulah sebabnya judul artikel ini "Kajian Semantik Prototipe terhadap istilah Desa Wisata di Dua Desa, Wilayah Sleman Yogyakarta". Oleh karena melibatkan pandangan masyarakat pada DW yang dipilih sebagai lokasi penelitian, perlu adanya teori fenomenologi untuk menerangkan fenomena istilah DW tersebut. Semantik prototipe hanya menerangkan penafsiran dan pemahaman terhadap istilah DW. Kajian semantik prototipe terhadap DW menuntut adanya penghitungan dan prosentasi yang pasti, dengan unsur-unsur atau komponen yang telah ditentukan oleh peneliti.

Keperluan hitung angka-angka presentasi atau statistik menjadi penting dalam kajian semantik prototipe DW untuk memudahkan berapa tingkat DW terhadap suatu wilayah. Tanpa penghitungan prosentase tersebut, suatu tempat atau desa akan sulit ditentukan sebagai DW atau bukan sesuai dengan kriteria yang telah ditentukan dalam penelitian ini. Artinya, penentuan istilah DW ini dapat saja sangat berbeda dengan yang ditentukan peneliti lain, bila menggunakan unsur atau variabel yang berbeda pula.

Fillmore (1975:128), Nida (1971, reprint 1975:184), dan Langacker (2008:3) menyatakan bahwa analisis semantik prototipe dilakukan dengan pendekatan struktural yang disebut dengan checklist atau componential analysis. Sayangnya, pendekatan seperti ini lebih mudah untuk menjelaskan kategori atau entitas tertentu yang bersifat konkret dan sederhana. Adapun untuk kategori atau entitas abstrak dan bertingkat, penjelasannya cenderung tidak memuaskan.

Oleh karena itu, untuk kategori atau entitas abstrak dan bertingkat, seperti istilah DW dalam penelitian ini, pendekatan checklist atau componential analysis tidak digunakan. Analisis yang digunakan adalah semantik prototipe dengan hitung probabilitas atau prosentase suatu keadaan dalam istilah DW. Semakin tinggi prosentase suatu keadaan atau desa, berarti semakin tinggi pula kategorinya untuk termasuk di dalam DW.

Adapun paradigma yang digunakan untuk memahami pandangan atau pemikiran masyarakat terhadap DW menggunakan fenomenologi. Dengan menggunakan fenomenologi peneliti dapat menerangkan apa yang dipikirkan dan dipahami masyarakat terhadap istilah DW. Edmund Hursserl (Kuswarno, 2009:10) menyatakan bahwa dengan fenomenologi kita dapat mempelajari bentuk-bentuk pengalaman dari sudut pandang orang yang mengalaminya secara langsung, seolaholah kita yang mengalaminya.

Fenomenologi tidak saja mengklasifikasikan setiap tindakan sadar yang dilakukan, tetapi juga meliputi prediksi terhadap tindakan di masa yang akan datang, dilihat dari aspek-aspek yang terkait dengannya. Semuanya bersumber dari bagaimana seseorang memaknai objek dalam pengalamannya. Oleh karena itu, tepatlah bila fenomenologi juga diartikan sebagai studi tentang makna, di mana makna itu lebih luas dari sekedar bahasa yang mewakilinya.

Apa yang dimaksud dengan DW? Sebagian besar masyarakat pasti sudah mengetahui apa yang dimaksud dengan DW. Umumnya masyarakat tidak dapat mendefinisikan dengan tepat apa yang dimaksud dengan DW. Di kalangan 
masyarakat ada banyak penerimaan dan penafsiran terhadap istilah DW. Mereka mendefinisikan dan menafsirkan istilah DW sesuai dengan latar belakang dan pemahamannya masing-masing.

Bagaimanapun, setiap anggota masyarakat memiliki pemikiran yang berbedabeda tentang istilah DW. Seorang peneliti tidak dapat menyalahkan masyarakat yang sudah memiliki pemahaman tertentu terhadap istilah DW. Tugas peneliti-lah untuk memberikan panduan bagaimana membuat definisi yang lebih komprehensif atas istilah DW tersebut. Dengan demikian istilah DW dapat diterima sebagai istilah baru secara lebih luas dan universal.

Wiendu Nuryanti (1993:2-3) menjelaskan bahwa DW adalah suatu bentuk integrasi antara atraksi, akomodasi, dan fasilitas pendukung yang disajikan dalam suatu struktur kehidupan masyarakat yang menyatu dengan tata cara dan tradisi yang berlaku. Pengertian tersebut hanya merupakan salah satu contoh pendefinisian terhadap istilah DW.

Ada sebagian masyarakat yang mengartikan DW sebagai kawasan pedesaan yang memiliki beberapa karakteristik khusus untuk menjadi daerah tujuan wisata, misalnya keindahan alam, kerajinan, atau makanan khas, dll. Di sisi lain ada sebagian masyarakat yang memaknai DW sebagai pengembangan dari suatu desa yang memiliki potensi wisata yang dilengkapi dengan fasilitas pendukung seperti alat transportasi atau penginapan.

Pendefinisian dan pemaknaan istilah DW tersebut tentu benar dan sah-sah saja. Bagaimanapun setiap individu pasti telah berusaha memaknai setiap fenomena yang ditemukannya berdasarkan latar belakang budaya dan pemikirannya. Tidak heran jika kemudian istilah DW melahirkan banyak sekali pengertian yang berbeda-beda.

Dari penjelasan tersebut di atas, penelitian ini dimaksudkan untuk mempelajari bentuk-bentuk pengalaman dari sudut pandang orang yang mengalaminya secara langsung. Selain itu, penelitian ini dapat pula diartikan sebagai studi tentang makna, di mana makna tersebut lebih luas dari sekedar bahasa yang mewakilinya ---"desa" dan "wisata" sebagaimana selama ini banyak dipahami masyarakat sebagai desa untuk tujuan wisata.

\section{Perumusan Masalah}

Berdasarkan latar belakang di atas, dapat dirumuskan masalah penelitian dalam satu pertanyaan: bagaimana definisi istilah DW menurut masyarakat dan apa saja unsur-unsur atau komponen-komponen yang harus ada di dalam DW tersebut?

\section{Tujuan Penelitian}

Penelitian ini bertujuan untuk mengetahui makna istilah DW; termasuk unsurunsur atau komponen-komponen yang terlibat di dalam istilah DW tersebut. Makna dan unsur-unsur dalam istilah DW tersebut disajikan di dalam Tabel 1, Tabel 2, dan Tabel 3 yang ada dalam artikel ini.

\section{Manfaat Penelitian}

Penelitian ini secara teoretis diharapkan dapat memperkaya kajian dalam bidang linguistik, terutama tentang pembentukan makna oleh masyarakat terhadap istilah DW. Penelitian ini diharapkan dapat menjelaskan tentang faktor-faktor yang menunjukkan konteks diri masyarakat yang berinteraksi dalam proses pembentukan 
makna DW. Teori-teori yang memberi manfaat dalam penelitian ini meliputi teori tindakan sosial, fenomenologi, interaksi simbolik, dan budaya.

Berikutnya, secara praktis penelitian ini diharapkan dapat membantu memecahkan masalah yang berkaitan dengan pendefinisian istilah DW bagi masyarakat. Pendefinisian istilah tersebut akan menjadi masukan bagi pihak-pihak yang berkepentingan, termasuk para pembuat kamus, pihak-pihak yang terlibat dalam industri pariwisata dan pemberdayaan desa menjadi DW, dan masyarakat luas yang ingin mengetahui lebih banyak tentang DW.

Dengan demikian setiap pihak memiliki pendefinisian yang lebih kurang sama terhadap DW yang ada di Indonesia. Pada akhirnya pendefinisian DW secara komprehensif, akan mengurangi perbedaan persepsi antara para pengambil keputusan, pelaku industri pariwisata, maupun masyarakat dalam mengembangkan potensi-potensi desa untuk menjadi DW demi untuk meningkatkan Pendapatan Asli Daerah (PAD) tiap wilayah. Dari pendefinisian yang tepat juga dapat dilakukan usaha-usaha yang menunjang pembukaan dan pembukaan DW-DW yang baru, seperti adanya penambahan infrastruktur, sarana dan prasarana budaya, penambahan SDM-SDM yang berkualitas sesuai dengan keperluan di wilayah DW, dan lain-lain.

\section{Kerangka Teori}

Kay dan Coleman (1981:6-44) menerangkan bahwa pandangan semantic prototipe "suatu kata" tergantung pada intuisi prateori yang melatarbelakangi kategori semantik. Hal ini biasanya memiliki sisi bias di antara para anggota yang memaknainya. Makna suatu kata, lebih dari sekedar "ya" atau "tidak", tetapi meliputi komponen-komponen yang dipahami oleh masing-masing personil bergantung dari pemikirannya terhadap kata tertentu.

Makna dari istilah DW lebih dari sekedar "DW" atau "bukan DW", tetapi meliputi komponen-komponen pembentuknya yang dipahami oleh masyarakat sebagai pemilik, pelaku, pengamat, dan penikmat dari DW yang bersangkutan. Prosentase dari komponen-komponen DW tersebut dihitung untuk menentukan apakah suatu desa termasuk di dalam makna "DW" atau "bukan DW".

Penggunaan teori semantik prototipe menurut Kay dan Coleman (1981:6-44) ini karena teori Fillmore (1975:128), Nida (Daftar pustaka1971, reprint 1975:184), dan Langacker (2008:3) menyatakan bahwa analisis semantik prototipe dengan checklist atau componential analysis akan lebih mudah untuk menjelaskan kategori atau entitas tertentu yang bersifat konkret dan sederhana, tetapi untuk kategori atau entitas abstrak dan bertingkat, penjelasannya cenderung tidak memuaskan. Adapun istilah DW peneliti anggap lebih mewakili kategori atau entitas abstrak dan bertingkat, bukan kategori konkret dan sederhana, seperti cangkir.

Sementara itu, teori fenomenologi dari Schutz (1967:7) mengemukakan bahwa orang secara aktif menginterpretasikan pengalamannya dengan memberi tanda dan arti tentang apa yang mereka lihat. Interpretasi merupakan proses aktif dalam menandai dan mengartikan tentang sesuatu yang diamati, seperti wacana, tindakan atau situasi bahkan pengalaman apapun. Wacana, tindakan, atau situasi bahkan pengalaman warga yang berkaitan dengan DW tidak dituliskan sebagaimana 
adanya, karena sudah diformulasikan dalam bentuk rumusan-rumusan data yang ada dalam Tabel 1, Tabel 2, dan Tabel 3 dalam artikel ini.

Schutz (1967:7) menjelaskan bahwa fenomenologi adalah studi tentang pengetahuan yang datang dari kesadaran atau cara kita memahami sebuah objek atau peristiwa melalui pengalaman sadar tentang objek atau peristiwa tersebut. Sebuah fenomena adalah penampilan sebuah objek, peristiwa atau kondisi dalam persepsi seseorang, jadi bersifat subjektif.

Tugas utama analisis fenomenologi adalah merekonstruksi dunia kehidupan manusia yang "sebenarnya" dalam bentuk yang mereka alami. Realitas dunia tersebut bersifat intersubjektif. Artinya sebagai anggota masyarakat, manusia akan berbagi persepsi dasar mengenai dunia yang mereka internalisasikan melalui sosialisasi dan memungkinkan mereka melakukan interaksi atau komunikasi (Mulyana, 2008:63). Dengan fenomenologi akan dapat diterangkan secara detail bagaimana persepsi masyarakat luas terhadap istilah DW.

Pandangan fenomenologi tidak dapat dilepaskan dari kajian semantic prototipe terhadap istilah DW karena unsur-unsur atau komponen-komponen yang ada di dalam DW baru dapat ditemukan dari pemikiran masyarakat atau warga setempat di lokasi penelitian. Tanpa adanya pemahaman terhadap fenomenologi dan rujukanrujukannya, unsur yang ada di dalam DW tidak dapat ditemukan.

Oleh karena itu, fenomenologi sebagai logos (discourse) atau wacana tentang fenomena harus memberikan suatu deskripsi setepat mungkin tentang apa yang hadir dan ada di hadapan kesadaran. Deskripsi ini harus lengkap dan dilakukan oleh kesadaran atau oleh subjek yang sepenuhnya sadar, subjek yang menulis, yang menjelaskan tentang apa yang telah dikatakan atau ditulis. Namun deskripsi yang tepat tidak akan pernah dapat dilakukan dengan tuntas (Ahimsa-Putra, 2009:8).

Senada dengan Ahimsa-Putra (2009:8) tersebut, dapatlah dimengerti kalau pemahaman masyarakat terhadap DW akan terus berkembang. Apa yang dipahami dan dimengerti oleh masyarakat terhadap istilah DW sekarang ini, bisa saja akan terus berkembang sesuai dengan perkembangan DW, atau bahkan menghilang dan tidak populer lagi bila kemudian program DW juga dihentikan. Sebagaimana masyarakat yang terus berkembang dan berubah, pemahaman terhadap istilahistilah pun akan terus mengalami perkembangan dan perubahan, baik dalam arti yang negatif atau positif.

Fenomenologi juga merupakan pendekatan yang beranggapan bahwa suatu fenomena bukanlah realitas yang berdiri sendiri. Fenomena yang tampak merupakan objek yang penuh dengan makna yang transendental. Dunia sosial keseharian tempat manusia hidup akan selalu penuh dengan sesuatu yang intersubjektif dan sarat dengan makna.

Dalam konteks fenomenologis, masyarakat adalah aktor yang melakukan tindakan sosial bersama aktor lainnya sehingga memiliki kesamaan dan kebersamaan dalam ikatan makna intersubjektif. Aktor tersebut memiliki historisitas dan dapat dilihat dalam bentuk yang alami. Mereka akan mengkonstruksikan makna dari luar atau dari arus utama pengalaman melalui proses tipifikasi. Dalam hal ini termasuk membentuk penggolongan atau klasifikasi dari pengalaman yang ada. Secara tanpa sadar, masyarakat juga telah membentuk penggolongan atau klasifikasi tertentu terhadap istilah DW. Mereka memasukkan suatu desa sebagai DW atau 
bukan, berdasarkan tipologi yang mereka pahami sesuai dengan latar belakang budayanya.

Teori tindakan sosial dari Max Weber (1864-1920) mendefinisikan tindakan sosial sebagai semua perilaku manusia ketika dan sejauh individu memberikan suatu makna subjektif terhadap perilaku tersebut (Mulyana, 2008:60). Dengan demikian, tindakan masyarakat terhadap kondisi DW sangat tergantung dari makna subjektif yang diberikannya. Mereka yang memahami DW secara luas, biasanya memberikan penghargaan yang lebih baik dan lebih peduli terhadap adanya DW.

Blumer (1986:2) menegaskan bahwa ada tiga asumsi yang mendasari tindakan manusia, yaitu (1) human being act toward things on the basic of the meaning that the things have for them, (2) the meaning of the things arises out of the social interaction one with one's fellow, (3) the meaning of things are handled in and modified through an interpretative process used by the person in dealing with the thing he encounters.

Dari pendapat tersebut dapat diterangkan bahwa (1) manusia bertindak terhadap sesuatu atas makna yang dimiliki oleh benda, kejadian, atau fenomena itu bagi mereka. Individu merespons lingkungan termasuk objek fisik (benda) dan objek sosial (perilaku) berdasarkan makna yang dikandung komponen tersebut bagi mereka; (2) makna terhadap sesuatu diberikan oleh manusia sebagai hasil interaksi dengan sesamanya. Artinya, makna yang diberikan tidak inherent, tidak terlekat pada benda ataupun fenomenanya, tetapi tergantung pada orang-orang yang terlibat di dalam interaksi tersebut; (3) makna yang diberikan akan ditangani dan dimodifikasi melalui proses interpretasi dalam rangka menghadapi fenomena tertentu lainnya.

Makna yang diinterpretasikan individu dapat berubah dari waktu ke waktu, sejalan dengan perubahan situasi yang ditemukan dalam interaksi sosial. Perubahan interpretasi dimungkinkan karena setiap individu dapat melakukan proses mental dengan berkomunikasi pada dirinya sendiri. Demikian pula makna yang diberikan masyarakat terhadap istilah DW. Istilah DW akan terus berubah sejalan dengan perkembangan dan perubahan masyarakat pendukungnya.

Adapun teori kebudayaan, lebih untuk menerangkan berbagai keadaan yang termasuk unsur-unsur kebudayaan dalam istilah DW. Misalnya suatu desa dianggap DW karena ada kuliner, kerajinan, adat istiadat tertentu, dll. yang merupakan unsur dari kebudayaan. Berdasarkan hal ini, maka teori kebudayaan yang sesuai untuk mengkaji DW ini adalah pendapat C. Kluckhohn (1962) yang mengemukakan ada tujuh unsur kebudayaan secara universal, yaitu (1) bahasa ---merupakan produk manusia sebagai homo languens, (2) sistem pengetahuan ---merupakan produk manusia sebagai homo sapiens, (3) sistem teknologi dan peralatan ---merupakan produk manusia sebagai homo faber, (4) sistem kesenian ---merupakan produk manusia sebagai homo esteticus, (5) sistem mata pencaharian hidup ---merupakan produk manusia sebagai homo economicus, (6) sistem religi ---merupakan produk manusia sebagai homo religius, dan (7) sistem kekerabatan dan organisasi kemasyarakatan ---merupakan produk manusia sebagai homo socius.

Oleh karena sifat universal unsur-unsur kebudayaan yang dikemukakan oleh C. Kluckhohn (1962) ini, maka dalam masyarakat yang paling primitif sekalipun, mereka pasti memiliki ketujuh unsur kebudayaan tersebut. Adapun yang 
membedakan masing-masing unsur kebudayaan itu dari masyarakat primitif dengan masyarakat yang lebih maju adalah tingkat kompleksitas unsur-unsur tersebut. Semakin primitif suatu masyarakat, maka unsur-unsur kebudayaannya semakin sederhana. Sebaliknya semakin maju suatu masyarakat, maka unsur-unsur kebudayaannya semakin komplek dan beragam.

Dengan demikian, teori semantik prototipe menentukan unsur-unsur pembentuk istilah DW ---yang ditopang dengan teori kebudayaan untuk menentukannya. Teori fenomenologi melihat bahwa orang-orang secara aktif menginterpretasikan pengalamannya dengan memberi tanda dan arti tentang istilah DW. Adapun teori interaksi simbolik melihat individu-individu berinteraksi dengan menggunakan simbol-simbol yang di dalamnya berisi tanda-tanda, isyarat dan katakata dalam memaknai istilah DW.

\section{Hipotesis}

Dengan pandangan fenomenologi sebagai pendukung kajian semantik prototipe terhadap istilah DW, sekurang-kurangnya unsur-unsur atau komponen dalam DW untuk menentukan suatu desa termasuk dalam "DW" atau "bukan DW" ada empat variabel terikat, yaitu (1) keindahan alam, (2) keterampilan penduduk, (3) kebudayaan, dan (4) kedatangan orang. Keempat variabel itulah yang menurut versi masyarakat menentukan suatu desa dapat disebut dengan "DW" atau "bukan DW".

Semakin sedikit variabel yang ada pada suatu desa, berarti semakin tidak memenuhi syarat desa tersebut sebagai DW. Sebaliknya, semakin banyak variabel tersebut yang ada pada suatu desa, berarti semakin memenuhi syarat sebagai DW. Syarat-syarat tersebut ditentukan oleh masyarakat di lokasi penelitian sebagai penentu definisi DW. Oleh karena mereka berada di wilayah DW, maka komponen yang mereka kenali semakin banyak. Dengan demikian, penentuan definisi istilah DW dalam artikel ini adalah kajian semantic prototipe dengan memperhatikan fenomena yang ada di lingkungan masyarakat DW.

\section{Metode dan Analisis}

Tahapan-tahapan fenomenologi Husserl (dalam Kuswarno, 2009:47-53) dapat diuraikan dalam empat tahap sebagai berikut. Pertama, epoche adalah pemutusan hubungan dengan pengalaman yang peneliti miliki sebelumnya. Epoche mutlak harus ada, terutama ketika menempatkan fenomena dalam kurung (bracketing method), memisahkan fenomena dari keseharian dan dari unsur-unsur fisiknya, dan ketika mengeluarkan "kemurnian" yang ada padanya. Jadi, epoche adalah cara untuk melihat dan menjadi, sebuah sikap mental yang bebas.

Kedua, reduksi, ketika epoche adalah langkah awal untuk "memurnikan" objek dari pengalaman dan prasangka awal, maka tugas dari reduksi fenomenologi adalah menjelaskan dalam susunan bahasa bagaimana objek itu terlihat. Tidak hanya dalam term objek secara eksternal, tetapi juga kesadaran dalam tindakan internal, pengalaman, ritme, dan hubungan antara fenomena "aku" sebagai subjek yang diamati. Fokusnya terletak pada kualitas pengalaman, sedangan tantangannya ada pada pemenuhan sifat-sifat alamiah dan makna dari pengalaman. Dengan demikian, proses ini terjadi lebih dari satu kali. 
Ketiga, variasi imajinasi adalah mencari makna-makna yang mungkin dengan memanfaatkan imajinasi, kerangka rujukan, pemisahan dan pembalikan, dan pendekatan terhadap fenomena dari perspektif, posisi, peranan dan fungsi yang berbeda. Tujuannya untuk mencapai deskripsi struktural dari sebuah pengalaman atau dengan kata lain menjelaskan struktur esensial dari fenomena.

Keempat, sintesis makna dan esensi, merupakan tahap terakhir dalam penelitian fenomenologi transendal yaitu integrasi intuitif dasar-dasar deskripsi tekstural dan struktural ke dalam suatu pernyataan yang menggambarkan hakikat fenomena secara keseluruhan. Tahap ini merupakan tahap penegakan pengetahuan mengenai hakikat.

Prosedur pengumpulan data pada penelitian fenomenologi sekurangnya ada tujuh langkah, seperti yang diterangkan oleh Creswell (1994:125), yaitu (1) penentuan lokasi atau individu, (2) membangun akses atau rapport, (3) memilih sampling secara purposif, (4) pengumpulan data di lapangan, (5) mencatat atau merekam informasi, (6) memecahkan isu-isu lapangan, (7) menyimpan data dan kembali lagi pada langkah awal.

Penelitian ini menggunakan kuesioner yang telah dirancang berdasarkan hipotesis yang disarikan dari observasi lapangan di Desa Tembi dan di Desa Ketingan, Sleman, Daerah Istimewa Yogyakarta mengenai definisi DW. Pada waktu itu disebarkan pertanyaan secara terbuka, "Apa definisi DW menurut Anda?"

Dari pertanyaan tersebut diperoleh rincian jawaban yang sangat luas, sekitar 48 rincian (65 rincian termasuk deskripsi identitas responden). Berdasarkan pernyataan tersebut dipadatkan agar mudah dipahami, sehingga terdapat empat variabel terikat, (1) keindahan alam, (2) keterampilan penduduk, (3) kebudayaan, dan (4) kedatangan orang.

Dari empat variabel terikat tersebut dapat disusun probabilitas pertanyaan dengan rumus:

$$
=2^{\mathrm{n}} \mathrm{p}(\mathrm{n})
$$

Di mana:

$\mathrm{p}=$ probabilitas.

$\mathrm{n}=$ variabel yang digunakan.

Dengan rumusan di atas dapat diperoleh 16 Cerita yang mengandung variabelvariabel yang digunakan; termasuk himpunan kosong (yang tidak mengandung variabel).

Tabel 1. Probabilitas Cerita untuk Mengetahui Semantik Prototipe DW

\begin{tabular}{|l|l|l|l|l|}
\hline No & Probabilitas Pertanyaan & \multicolumn{3}{|l|}{ Ada atau tidaknya variabel } \\
& $\begin{array}{l}\mathrm{p}(\mathrm{n})=2^{\mathrm{n}} \\
\mathrm{p}=\text { probabilitas } \\
\mathrm{n}=\text { variabel yang } \\
\text { digunakan, ada 4, berarti } \\
\mathrm{p}(4)=2^{4}=16\end{array}$ & $\begin{array}{l}\text { Bila ada berarti + (positif), bila tidak } \\
\text { ada berarti }- \text { (negatif). Nilai paling } \\
\text { tinggi adalah yang memiliki 4 variabel } \\
\text { atau 4+ }\end{array}$ \\
\cline { 2 - 6 } & A & B & C & D \\
\hline
\end{tabular}




\begin{tabular}{|l|l|l|l|l|l|}
\hline 1 & & - & - & - & - \\
\hline 2 & & + & - & - & - \\
\hline 3 & - & + & - & - \\
\hline 4 & - & - & + & - \\
\hline 5 & - & - & - & + \\
\hline 6 & & + & + & - & - \\
\hline 7 & + & - & + & - \\
\hline 8 & & + & - & - & + \\
\hline 9 & - & + & + & - \\
\hline 10 & - & - & + & - & + \\
\hline 11 & - & - & + & + \\
\hline 12 & & - & + & + & - \\
\hline 13 & & + & + & - & + \\
\hline 14 & & + & - & + & + \\
\hline 15 & & + & + & + & + \\
\hline 16 & & - & + & + & + \\
\hline
\end{tabular}

\section{Keterangan:}
A. Keindahan alam
B. Keterampilan penduduk
C. Kebudayaan
D. Kedatangan orang

Dari probabilitas yang disusun pada Tabel 1, masing-masing akan dibuat Cerita agar lebih mudah dipahami masyarakat. Masing-masing cerita mengandung variabel terikat seperti yang telah ditandai dengan plus (+) dan minus (-). Cerita 1, tidak mengandung satu variabel yang digunakan untuk mengetahui prototipe semantik DW. Cerita 2 mengandung 1 variabel, yaitu keindahan alam, dan seterusnya hingga Cerita 16 yang mengandung 4 variabel yang digunakan untuk mengetahui prototipe semantik DW. Setiap tanda plus (+) menyatakan variabel yang tersedia dalam cerita. Sebaliknya tanda minus (-) berarti tidak terdapat variabel dalam cerita tersebut.

Cerita kontrol-nya terdapat pada Cerita 16, yang mengandung semua variabel dan digunakan untuk mengetahui prototipe semantik DW. Bila responden menjawab nomor 16 dengan pernyataan 5, berarti ia serius dan sungguh-sungguh memberikan pendapatnya pada kuesioner yang diberikan dan seluruh penilaiannya dapat dianggap valid. Namun bila tidak, maka bisa disimpulkan bahwa responden tersebut tidak serius dan jawaban dari seluruh penilaiannya dapat diabaikan, atau tidak dihitung.

Tabel 2 berikut adalah Daftar Cerita yang dibuat dalam bentuk kuesioner agar lebih mudah dipahami. Kuesioner diberikan kepada 50 orang masyarakat umum sebagai sampel yang diambil secara acak di sekitar lingkungan kampus Universitas Gadjah Mada. 


\section{Contoh Kuesioner yang diberikan kepada responden}

Kepada Yth Bapak/Ibu/Sdr.

Silakan lingkari yang paling sesuai dengan identitas Anda!

Kisaran Umur : 25/35/45/55/65 tahun

Jenis Kelamin : L/P

Pendidikan

: SMU/S-1/S-2/S-3

Pekerjaan

: Pegawai/Non Pegawai

Mohon bantuan dan waktunya untuk berkenan mengisi kuesioner tentang definisi "Desa Wisata" berikut ini.

\begin{tabular}{|c|c|c|c|c|c|c|}
\hline \multirow[t]{2}{*}{$\mathrm{No}$} & \multirow[t]{2}{*}{$\begin{array}{l}\text { Cerita : } \\
\text { Menurut Anda, apakah pernyataan- } \\
\text { pernyataan di bawah ini merupakan 'desa } \\
\text { wisata'? Berilah penilaian sesuai dengan } \\
\text { pandangan Anda pada kolom penilaian! }\end{array}$} & \multicolumn{5}{|c|}{$\begin{array}{l}\text { Penilaian: } \\
\text { Berilah tanda silang }(X) \text { pada } \\
\text { bagian yang Anda anggap } \\
\text { sesuai dengan pandangan } \\
\text { Anda! }\end{array}$} \\
\hline & & $\begin{array}{c}1 \\
\text { STS }\end{array}$ & $\begin{array}{c}2 \\
\text { TS }\end{array}$ & $\begin{array}{l}3 \\
\mathrm{R}\end{array}$ & $\begin{array}{l}4 \\
S\end{array}$ & $\begin{array}{c}5 \\
\text { SS }\end{array}$ \\
\hline 1 & $\begin{array}{l}\text { Desa A sangat ramai karena berada di dekat } \\
\text { terminal yang menjadi tempat perhentian bus } \\
\text { antar kota dan lalu lalang orang yang } \\
\text { bepergian. }\end{array}$ & & & & & \\
\hline 2 & $\begin{array}{l}\text { Desa B daerahnya indah, ada daerah pantai. } \\
\text { Penduduknya bekerja beraneka ragam. Akses } \\
\text { jalan masih sulit sehingga daerah tersebut } \\
\text { tidak banyak dikunjungi orang. }\end{array}$ & & & & & \\
\hline 3 & $\begin{array}{l}\text { Desa C merupakan desa di dataran rendah. } \\
\text { Penduduknya pandai menari dan membuat } \\
\text { kerajinan wayang kulit. Sayang, belum banyak } \\
\text { orang luar yang datang ke desa tersebut. }\end{array}$ & & & & & \\
\hline 4 & $\begin{array}{l}\text { Desa D merupakan desa yang terkenal dengan } \\
\text { seni jathilan. Kelompok-kelompok seni tersebut } \\
\text { berkeliling sampai ke luar desa, tapi di desa D } \\
\text { jarang ada orang menyaksikan seni jathilan. }\end{array}$ & & & & & \\
\hline 5 & $\begin{array}{l}\text { Desa E merupakan desa keramat yang banyak } \\
\text { dikunjungi orang. Di sana terdapat makam } \\
\text { salah satu tokoh yang dianggap sesepuh sakti } \\
\text { dan mampu memberi berkah pada mereka } \\
\text { yang memintanya. }\end{array}$ & & & & & \\
\hline 6 & $\begin{array}{l}\text { Desa F memiliki kebun-kebun strowberry yang } \\
\text { indah. Penduduknya sangat pandai membuat } \\
\text { olahan panganan dari buah strowberry. }\end{array}$ & & & & & \\
\hline 7 & $\begin{array}{l}\text { Desa G adalah desa di dataran rendah. } \\
\text { Penduduknya menata lingkungan menjadi }\end{array}$ & & & & & \\
\hline
\end{tabular}




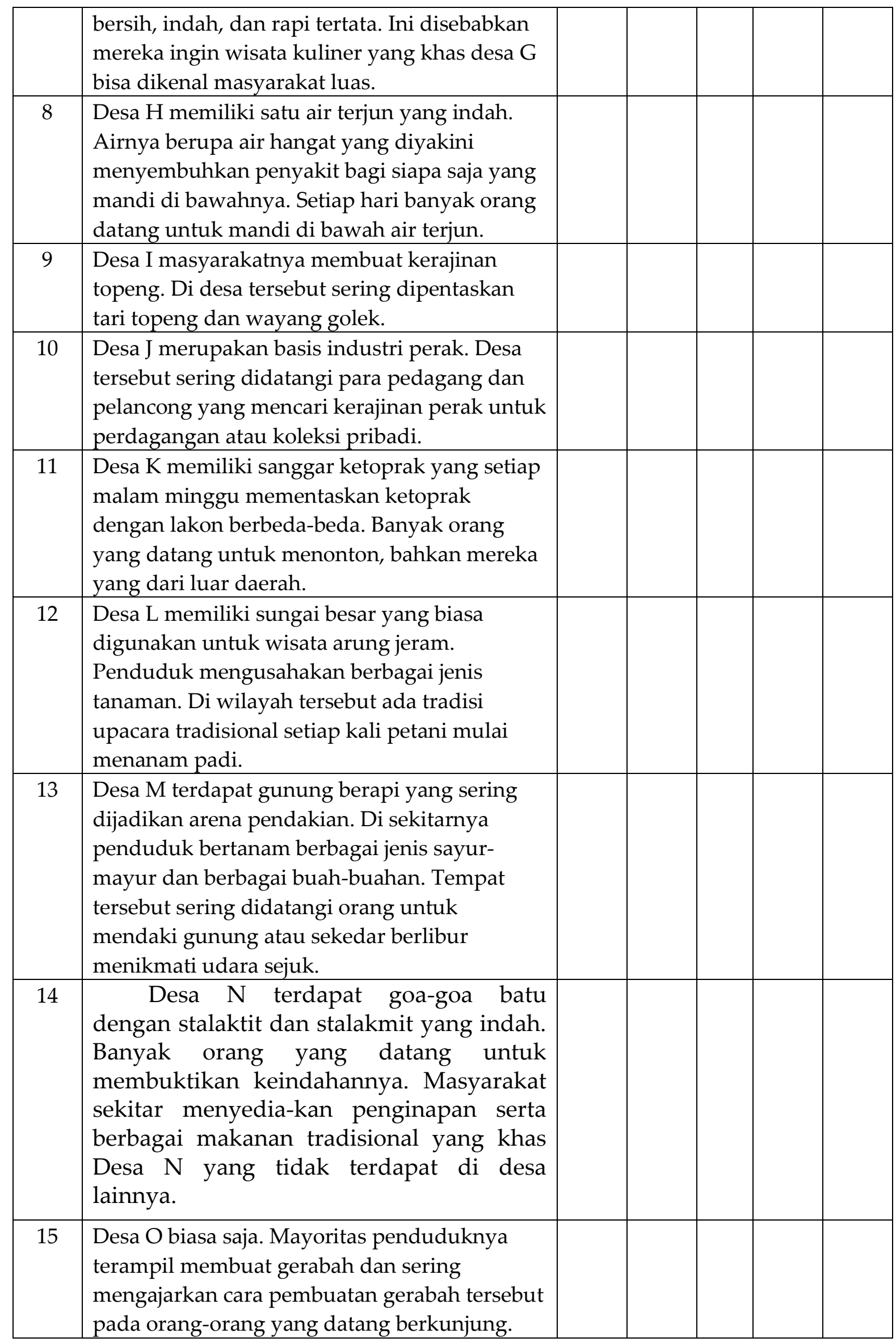




\begin{tabular}{|l|l|l|l|l|l|l|}
\hline 16 & $\begin{array}{l}\text { Desa P memiliki alam perkebunan yang indah. } \\
\text { Penduduknya mengusahakan kerajinan. Di } \\
\text { desa tersebut ada banyak makanan khas dan } \\
\text { kesenian unik yang membuat banyak orang } \\
\text { datang berkunjung. }\end{array}$ & & & & & \\
\hline
\end{tabular}

\section{Keterangan:}

Skor penilaian terdiri dari 5, yaitu mulai dari yang terendah:

1. Sangat Tidak Setuju (STS)

2. Tidak Setuju (TS)

3. Ragu-ragu (R)

4. Setuju (S)

5. Sangat Setuju (SS)

Nama desa sengaja tidak dipublikasin

Skala 1-5 ini diadaptasi dari Coleman dan Kay (1981:6-44).

Jawaban dari para responden tersebut dihitung dan dianalisis dengan berpedoman pada variabel yang telah ditetapkan. Dari 50 kuesioner yang disebarkan hanya 40 yang valid, karena 6 orang menjawab antara 1-3 pada Cerita 16, berarti ia tidak serius mengerjakan kuesioner tersebut; sedangkan 4 orang lainnya tidak mengembalikan kuesioner.

Proses analisis data dalam penelitian ini menggunakan metode deduktif karena bersifat membuktikan hipotesis. Analisis dilakukan untuk membuktikan hipotesis yang telah disusun berdasarkan penelitian pendahuluan, sebelum penelitian yang sebenarnya dilakukan. Tabel 3 berikut adalah frekuensi jawaban dari para responden.

Tabel 3. Frekuensi Jawaban dari Para Responden

\begin{tabular}{|c|c|c|c|c|c|c|}
\hline \multirow[t]{2}{*}{ No } & \multirow[t]{2}{*}{$\begin{array}{l}\text { Cerita : } \\
\text { Menurut Anda, apakah pernyataan-pernyataan di } \\
\text { bawah ini merupakan 'desa wisata'? Berilah } \\
\text { penilaian sesuai dengan pandangan Anda pada } \\
\text { kolom penilaian! }\end{array}$} & \multicolumn{5}{|c|}{$\begin{array}{l}\text { Penilaian: } \\
\text { Berilah tanda silang }(X) \text { pada } \\
\text { bagian yang Anda anggap } \\
\text { sesuai dengan pandangan } \\
\text { Anda! }\end{array}$} \\
\hline & & $\begin{array}{l}1 \\
\text { STS }\end{array}$ & $\begin{array}{l}2 \\
\text { TS }\end{array}$ & $\begin{array}{l}3 \\
\mathrm{R}\end{array}$ & $\begin{array}{l}4 \\
S\end{array}$ & $\begin{array}{l}5 \\
\text { SS }\end{array}$ \\
\hline 1 & $\begin{array}{l}\text { Desa A sangat ramai karena berada di dekat } \\
\text { terminal yang menjadi tempat perhentian bus antar } \\
\text { kota dan lalu lalang orang yang bepergian. }\end{array}$ & 35 & 4 & 1 & 0 & 0 \\
\hline 2 & $\begin{array}{l}\text { Desa B daerahnya indah penuh pantai-pantai luar } \\
\text { biasa. Penduduknya bekerja beraneka ragam. } \\
\text { Akses jalan masih sulit sehingga daerah tersebut } \\
\text { tidak banyak dikunjungi orang. }\end{array}$ & 30 & 2 & 2 & 3 & 3 \\
\hline 3 & $\begin{array}{l}\text { Desa C merupakan desa di dataran rendah. } \\
\text { Penduduknya pandai menari dan membuat } \\
\text { kerajinan wayang kulit. Sayang, belum banyak }\end{array}$ & 30 & 3 & 1 & 2 & 4 \\
\hline
\end{tabular}




\begin{tabular}{|c|c|c|c|c|c|c|}
\hline & orang luar yang datang ke desa tersebut. & & & & & \\
\hline 4 & $\begin{array}{l}\text { Desa D merupakan desa yang terkenal dengan seni } \\
\text { jathilan. Kelompok-kelompok seni tersebut } \\
\text { berkeliling sampai ke luar desa, tapi di desa D } \\
\text { jarang ada orang menyaksikan seni jathilan. }\end{array}$ & 20 & 2 & 5 & 5 & 8 \\
\hline 5 & $\begin{array}{l}\text { Desa E merupakan desa keramat yang banyak } \\
\text { dikunjungi orang. Di sana terdapat makam salah } \\
\text { satu tokoh yang dianggap sesepuh sakti dan } \\
\text { mampu memberi berkah pada mereka yang } \\
\text { memintanya. }\end{array}$ & 10 & 11 & 2 & 7 & 10 \\
\hline 6 & $\begin{array}{l}\text { Desa F memiliki kebun-kebun strowberry yang } \\
\text { indah. Penduduknya sangat pandai membuat } \\
\text { olahan panganan dari buah strowberry. }\end{array}$ & 7 & 6 & 7 & 7 & 13 \\
\hline 7 & $\begin{array}{l}\text { Desa G adalah desa di dataran rendah. } \\
\text { Penduduknya menata lingkungan menjadi bersih, } \\
\text { indah, dan rapi tertata. Ini disebabkan } \\
\text { mereka ingin wisata kuliner yang khas desa G bisa } \\
\text { dikenal masyarakat luas. }\end{array}$ & 5 & 8 & 5 & 8 & 14 \\
\hline 8 & $\begin{array}{l}\text { Desa H memiliki satu air terjun yang luar biasa } \\
\text { indah. Airnya berupa air hangat yang diyakini } \\
\text { menyembuhkan berbagai penyakit bagi siapa saja } \\
\text { yang mandi di bawahnya. Setiap hari banyak } \\
\text { orang datang untuk mandi di bawah air terjun. }\end{array}$ & 2 & 1 & 12 & 9 & 16 \\
\hline 9 & $\begin{array}{l}\text { Desa I masyarakatnya membuat kerajinan topeng. } \\
\text { Di desa tersebut sering dipentaskan tari topeng } \\
\text { dan wayang golek. }\end{array}$ & 0 & 2 & 10 & 10 & 18 \\
\hline 10 & $\begin{array}{l}\text { Desa J merupakan basis industri perak. Desa } \\
\text { tersebut sering didatangi para pedagang dan } \\
\text { pelancong yang mencari kerajinan perak untuk } \\
\text { perdagangan atau koleksi pribadi. }\end{array}$ & 0 & 5 & 5 & 10 & 20 \\
\hline 11 & $\begin{array}{l}\text { Desa K memiliki sanggar ketoprak yang setiap } \\
\text { malam minggu mementaskan ketoprak dengan } \\
\text { lakon berbeda-beda. Banyak orang yang datang } \\
\text { untuk menonton, bahkan mereka yang dari luar } \\
\text { daerah. }\end{array}$ & 0 & 1 & 2 & 11 & 26 \\
\hline 12 & $\begin{array}{l}\text { Desa L memiliki sungai besar yang biasa } \\
\text { digunakan untuk wisata arung jeram. Penduduk } \\
\text { mengusahakan berbagai jenis tanaman. Di wilayah } \\
\text { tersebut ada tradisi upacara tradisional setiap kali } \\
\text { petani mulai menanam padi. }\end{array}$ & 0 & 1 & 2 & 8 & 29 \\
\hline 13 & $\begin{array}{l}\text { Desa } \mathrm{M} \text { terdapat gunung berapi yang sering } \\
\text { dijadikan arena pendakian. Di sekitarnya } \\
\text { penduduk bertanam berbagai jenis sayur-mayur } \\
\text { dan berbagai buah-buahan. Tempat tersebut sering } \\
\text { didatangi orang untuk mendaki gunung atau } \\
\text { sekedar berlibur menikmati udara sejuk. }\end{array}$ & 0 & 0 & 1 & 7 & 32 \\
\hline 14 & $\begin{array}{l}\text { Desa N terdapat goa-goa batu dengan stalaktit dan } \\
\text { stalakmit yang indah. Banyak orang yang datang } \\
\text { untuk membuktikan keindahannya. Masyarakat } \\
\text { sekitar menyediakan penginapan serta berbagai }\end{array}$ & 0 & 0 & 2 & 3 & 35 \\
\hline
\end{tabular}




\begin{tabular}{|l|l|l|l|l|l|l|}
\hline & $\begin{array}{l}\text { makanan tradisional yang khas Desa N yang tidak } \\
\text { terdapat di desa lainnya. }\end{array}$ & $\begin{array}{l}\text { Desa O biasa saja. Mayoritas penduduknya } \\
\text { terampil membuat gerabah dan sering } \\
\text { mengajarkan cara pembuatan gerabah tersebut } \\
\text { pada orang-orang yang datang berkunjung. }\end{array}$ & 0 & 0 & 0 & 3 \\
\hline 16 & $\begin{array}{l}\text { Desa P memiliki alam perkebunan yang indah. } \\
\text { Penduduknya mengusahakan kerajinan. Di desa } \\
\text { tersebut ada banyak makanan khas dan kesenian } \\
\text { unik yang membuat banyak orang datang } \\
\text { berkunjung. }\end{array}$ & 0 & 0 & 0 & 0 & 40 \\
\hline
\end{tabular}

Setelah analisis data akan dilakukan penyusunan satuan-satuan yang dianggap sebagai "data yang valid" dan selanjutnya dapat ditafsirkan dan diolah sebagai hasil penelitian. Hasil penelitian diperoleh dari frekuensi jawaban kuesioner yang diajukan kepada responden, yang selanjutnya akan diuraikan hasil analisis dalam poin hasil dan pembahasan. Pada tahap penyajian data merupakan penyajian sekumpulan informasi yang tersusun yang memberikan kemungkinan adanya penarikan kesimpulan sebagai verifikasi dari makna-makna yang muncul dari data yang harus diuji kebenaran atau validitasnya.

\section{HASIL DAN PEMBAHASAN}

Dari Tabel 3, dapat digambarkan bahwa skala jawaban yang dipilih oleh 40 responden adalah sebagai berikut.

Cerita 1: Desa A

\begin{tabular}{|c|c|c|c|c|}
\hline Skala & Frekuensi & $\begin{array}{c}\text { Persentase } \\
(\%)\end{array}$ & $\begin{array}{c}\text { Persentase yang } \\
\text { Valid }(\%)\end{array}$ & $\begin{array}{c}\text { Persentase } \\
\text { Kumulatif }(\%)\end{array}$ \\
\hline 3 & 35 & 87,5 & 87,5 & 87,5 \\
2 & 4 & 10 & 10 & 97,5 \\
1 & 1 & 2,5 & 2,5 & 100 \\
Total & 40 & 100 & 100 & \\
\hline
\end{tabular}

Cerita 2: Desa B

\begin{tabular}{|c|c|c|c|c|}
\hline Skala & Frekuensi & Persentase (\%) & $\begin{array}{l}\text { Persentase yang } \\
\text { Valid (\%) }\end{array}$ & $\begin{array}{l}\text { Persentase } \\
\text { Kumulatif (\%) }\end{array}$ \\
\hline 5 & 3 & 7,5 & 7,5 & 7,5 \\
4 & 3 & 7,5 & 7,5 & 15 \\
3 & 2 & 5 & 5 & 20 \\
2 & 2 & 5 & 5 & 25 \\
1 & 30 & 75 & 75 & 100 \\
Total & 40 & 100 & 100 & \\
\hline
\end{tabular}

Cerita 3: Desa C

\begin{tabular}{|c|c|c|c|c|}
\hline Skala & Frekuensi & $\begin{array}{c}\text { Persentase } \\
(\%)\end{array}$ & $\begin{array}{c}\text { Persentase } \\
\text { yang Valid (\%) }\end{array}$ & $\begin{array}{c}\text { Persentase } \\
\text { Kumulatif (\%) }\end{array}$ \\
\hline 5 & 4 & 10 & 10 & 10 \\
4 & 2 & 5 & 5 & 15 \\
\hline
\end{tabular}




\begin{tabular}{|c|c|c|c|c|}
\hline 3 & 1 & 2,5 & 2,5 & 17,5 \\
2 & 3 & 7,5 & 7,5 & 25 \\
1 & 30 & 75 & 75 & \\
Total & 40 & 100 & 100 & 100 \\
\hline
\end{tabular}

Cerita 4: Desa D

\begin{tabular}{|c|c|c|c|c|}
\hline Skala & Frekuensi & $\begin{array}{c}\text { Persentase } \\
(\%)\end{array}$ & $\begin{array}{c}\text { Persentase yang } \\
\text { Valid }(\%)\end{array}$ & $\begin{array}{c}\text { Persentase } \\
\text { Kumulatif }(\%)\end{array}$ \\
\hline 5 & 8 & 20 & 20 & 20 \\
4 & 5 & 12,5 & 12,5 & 32,5 \\
3 & 5 & 12,5 & 12,5 & 45 \\
2 & 2 & 5 & 5 & 50 \\
1 & 20 & 50 & 50 & 100 \\
Total & 40 & 100 & 100 & \\
\hline
\end{tabular}

Cerita 5: Desa E

\begin{tabular}{|c|c|c|c|c|}
\hline Skala & Frekuensi & $\begin{array}{c}\text { Persentase } \\
(\%)\end{array}$ & $\begin{array}{c}\text { Persentase yang } \\
\text { Valid }(\%)\end{array}$ & $\begin{array}{c}\text { Persentase } \\
\text { Kumulatif }(\%)\end{array}$ \\
\hline 5 & 10 & 25 & 25 & 25 \\
4 & 7 & 17,5 & 17,5 & 42,5 \\
3 & 2 & 5 & 5 & 47,5 \\
2 & 11 & 27,5 & 27,5 & 75 \\
1 & 10 & 25 & 25 & 100 \\
Total & 40 & 100 & 100 & \\
\hline
\end{tabular}

Cerita 6: Desa F

\begin{tabular}{|c|c|c|c|c|}
\hline Skala & Frekuensi & $\begin{array}{c}\text { Persentase } \\
(\%)\end{array}$ & $\begin{array}{c}\text { Persentase yang } \\
\text { Valid (\%) }\end{array}$ & $\begin{array}{c}\text { Persentase } \\
\text { Kumulatif (\%) }\end{array}$ \\
\hline 5 & 13 & 32,5 & 32,5 & 32,5 \\
4 & 7 & 17,5 & 17,5 & 50 \\
3 & 7 & 17,5 & 17,5 & 67,5 \\
2 & 6 & 15 & 15 & 82,5 \\
1 & 7 & 17,5 & 17,5 & 100 \\
Total & 40 & 100 & 100 & \\
\hline
\end{tabular}

Cerita 7: Desa G

\begin{tabular}{|c|c|c|c|c|}
\hline Skala & Frekuensi & $\begin{array}{c}\text { Persentase } \\
(\%)\end{array}$ & $\begin{array}{c}\text { Persentase yang } \\
\text { Valid (\%) }\end{array}$ & $\begin{array}{c}\text { Persentase } \\
\text { Kumulatif (\%) }\end{array}$ \\
\hline 5 & 14 & 35 & 35 & 35 \\
4 & 8 & 20 & 20 & 55 \\
3 & 5 & 12,5 & 12,5 & 67,5 \\
2 & 8 & 20 & 20 & 87,5 \\
1 & 5 & 12,5 & 12,5 & 100 \\
Total & 40 & 100 & 100 & \\
\hline
\end{tabular}

Cerita 8: Desa H

\begin{tabular}{|c|c|c|c|c|}
\hline Skala & Frekuensi & $\begin{array}{c}\text { Persentase } \\
(\%)\end{array}$ & $\begin{array}{c}\text { Persentase yang } \\
\text { Valid (\%) }\end{array}$ & $\begin{array}{c}\text { Persentase } \\
\text { Kumulatif }(\%)\end{array}$ \\
\hline 5 & 16 & 40 & 40 & 40 \\
\hline
\end{tabular}




\begin{tabular}{|c|c|c|c|c|}
\hline 4 & 9 & 22,5 & 22,5 & 62,5 \\
3 & 12 & 30 & 30 & 92,5 \\
2 & 1 & 2,5 & 2,5 & 95 \\
1 & 2 & 5 & 5 & \\
Total & 40 & 100 & 100 & 100 \\
\hline
\end{tabular}

Cerita 9: Desa I

\begin{tabular}{|c|c|c|c|c|}
\hline Skala & Frekuensi & $\begin{array}{c}\text { Persentase } \\
(\%)\end{array}$ & $\begin{array}{c}\text { Persentase yang } \\
\text { Valid (\%) }\end{array}$ & $\begin{array}{c}\text { Persentase } \\
\text { Kumulatif (\%) }\end{array}$ \\
\hline 5 & 18 & 45 & 45 & 45 \\
4 & 10 & 25 & 25 & 70 \\
3 & 10 & 25 & 25 & 95 \\
2 & 2 & 5 & 5 & 100 \\
Total & 40 & 100 & 100 & \\
\hline
\end{tabular}

Cerita 10: Desa J

\begin{tabular}{|c|c|c|c|c|}
\hline Skala & Frekuensi & $\begin{array}{c}\text { Persentase } \\
(\%)\end{array}$ & $\begin{array}{c}\text { Persentase yang } \\
\text { Valid }(\%)\end{array}$ & $\begin{array}{c}\text { Persentase } \\
\text { Kumulatif }(\%)\end{array}$ \\
\hline 5 & 20 & 50 & 50 & 50 \\
4 & 10 & 25 & 25 & 75 \\
3 & 5 & 12,5 & 12,5 & 87,5 \\
2 & 5 & 12,5 & 12,5 & \\
Total & 40 & 100 & 100 & 100 \\
\hline
\end{tabular}

Cerita 11: Desa K

\begin{tabular}{|c|c|c|c|c|}
\hline Skala & Frekuensi & $\begin{array}{c}\text { Persentase } \\
(\%)\end{array}$ & $\begin{array}{c}\text { Persentase yang } \\
\text { Valid }(\%)\end{array}$ & $\begin{array}{c}\text { Persentase } \\
\text { Kumulatif }(\%)\end{array}$ \\
\hline 5 & 26 & 65 & 65 & 65 \\
4 & 11 & 27,5 & 27,5 & 92,5 \\
3 & 2 & 5 & 5 & 97,5 \\
2 & 1 & 2,5 & 2,5 & \\
Total & 40 & 100 & 100 & 100 \\
\hline
\end{tabular}

Cerita 12: Desa L

\begin{tabular}{|c|c|c|c|c|}
\hline Skala & Frekuensi & $\begin{array}{c}\text { Persentase } \\
(\%)\end{array}$ & $\begin{array}{c}\text { Persentase yang } \\
\text { Valid }(\%)\end{array}$ & $\begin{array}{c}\text { Persentase } \\
\text { Kumulatif }(\%)\end{array}$ \\
\hline 5 & 29 & 72,5 & 72,5 & 72,5 \\
4 & 8 & 20 & 20 & 92,5 \\
3 & 2 & 5 & 5 & 97,5 \\
2 & 1 & 2,5 & 2,5 & \\
Total & 40 & 100 & 100 & 100 \\
\hline
\end{tabular}

Cerita 13: Desa M

\begin{tabular}{|c|c|c|c|c|}
\hline Skala & Frekuensi & $\begin{array}{c}\text { Persentase } \\
(\%)\end{array}$ & $\begin{array}{c}\text { Persentase yang } \\
\text { Valid (\%) }\end{array}$ & $\begin{array}{c}\text { Persentase } \\
\text { Kumulatif }(\%)\end{array}$ \\
\hline 5 & 32 & 80 & 80 & 80 \\
4 & 7 & 17,5 & 17,5 & 97,5 \\
3 & 1 & 2,5 & 2,5 & 100 \\
Total & 40 & 100 & 100 & \\
\hline
\end{tabular}


Cerita 14: Desa N

\begin{tabular}{|c|c|c|c|c|}
\hline Skala & Frekuensi & $\begin{array}{c}\text { Persentase } \\
(\%)\end{array}$ & $\begin{array}{c}\text { Persentase yang } \\
\text { Valid } \\
(\%)\end{array}$ & $\begin{array}{c}\text { Persentase } \\
\text { Kumulatif } \\
(\%)\end{array}$ \\
\hline 5 & 35 & 87,5 & 87,5 & 87,5 \\
4 & 3 & 7,5 & 7,5 & 95 \\
3 & 2 & 5 & 5 & 100 \\
Total & 40 & 100 & 100 & \\
\hline
\end{tabular}

Cerita 15: Desa O

\begin{tabular}{|c|c|c|c|c|}
\hline Skala & Frekuensi & $\begin{array}{c}\text { Persentase } \\
(\%)\end{array}$ & $\begin{array}{c}\text { Persentase yang } \\
\text { Valid }(\%)\end{array}$ & $\begin{array}{c}\text { Persentase } \\
\text { Kumulatif }(\%)\end{array}$ \\
\hline 5 & 37 & 92,5 & 92,5 & 92,5 \\
4 & 3 & 7,5 & 7,5 & 100 \\
Total & 40 & 100 & 100 & 100 \\
\hline
\end{tabular}

Cerita 16: Desa P

\begin{tabular}{|c|c|c|c|c|}
\hline Skala & Frekuensi & $\begin{array}{c}\text { Persentase } \\
(\%)\end{array}$ & $\begin{array}{c}\text { Persentase yang } \\
\text { valid (\%) }\end{array}$ & $\begin{array}{c}\text { Persentase } \\
\text { Kumulatif (\%) }\end{array}$ \\
\hline 5 & 40 & 100 & 100 & 100 \\
Total & 40 & 100 & 100 & \\
\hline
\end{tabular}

Dengan demikian kita bisa menjumlahkan cerita pada bagian ini. Dari 40 responden, nilai yang maksimum adalah $200(40 \times 5=200)$ dan nilai minimum adalah $40(40 \times 1=40)$. Nilai rata-rata (mean score) merupakan jumlah total dibagi 40 . Tabel 4 berikut ini adalah tabel yang mendeskripsikan hasil dari responden.

Tabel 4. Hasil dari Responden

\begin{tabular}{|c|l|c|c|}
\hline No & Cerita & $\begin{array}{c}\text { Jumlah Keseluruhan } \\
\text { (Total = Skala x Frekuensi) }\end{array}$ & $\begin{array}{c}\text { Jumlah Rata-rata } \\
\text { (Jumlah Keseluruhan/40) }\end{array}$ \\
\hline 1 & Desa A & 46 & 1,15 \\
\hline 2 & Desa B & 67 & 1,67 \\
\hline 3 & Desa C & 67 & 1,67 \\
\hline 4 & Desa D & 99 & 2,47 \\
\hline 5 & Desa E & 116 & 2,90 \\
\hline 6 & Desa F & 133 & 3,30 \\
\hline 7 & Desa G & 138 & 3,80 \\
\hline 8 & Desa H & 156 & 3,90 \\
\hline 9 & Desa I & 164 & 4,10 \\
\hline 10 & Desa J & 165 & 4,12 \\
\hline 11 & Desa K & 182 & 4,55 \\
\hline 12 & Desa L & 185 & 4,62 \\
\hline 13 & Desa M & 191 & 4,77 \\
\hline 14 & Desa N & 193 & 4,82 \\
\hline 15 & Desa O & 197 & 4,92 \\
\hline 16 & Desa P & 200 & 5 \\
\hline
\end{tabular}


Jumlah rata-rata menunjukkan desa mana yang dianggap sebagai DW dan bukan DW. Grafiknya dari kondisi tersebut dapat digambarkan sebagai berikut.

Grafik 1. Rata-rata Penilaian Responden

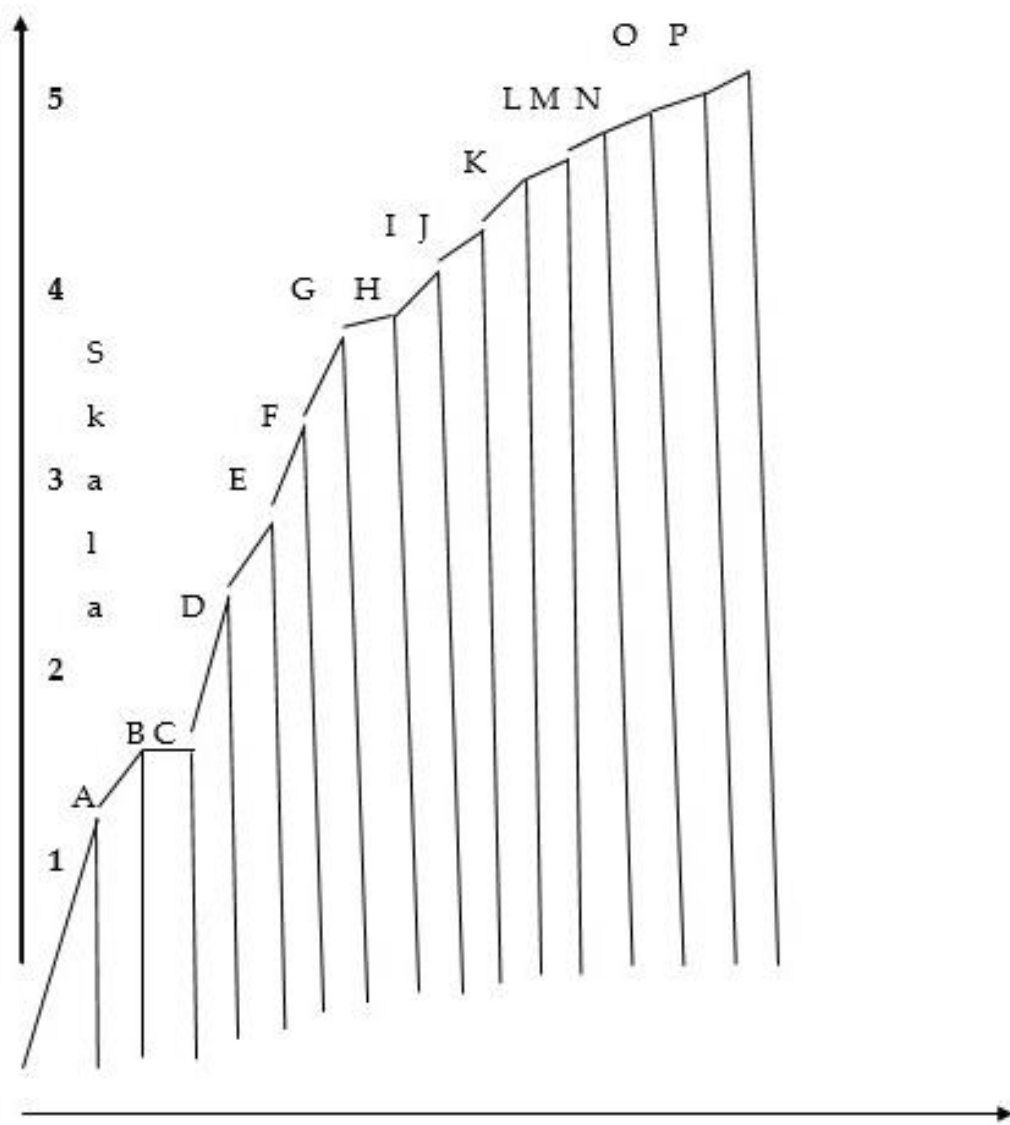

A B C D E F G H I J K L M N O P

Desa

Nilai rata-rata dalam setiap cerita menunjukkan tingkatan DW (grafik 1). Dari 16 cerita, Desa P mengandung empat variabel yang menyatakan DW (keindahan alam, keterampilan penduduk, kebudayaan, dan kedatangan orang). Hasil responden ini senada dengan hipotesis yang telah dinyatakan sebelumnya bahwa DW mengandung empat variabel (keindahan alam, keterampilan penduduk, kebudayaan, dan kedatangan orang).

Semakin banyak variabel yang terkandung di dalam cerita, maka semakin tinggi pula kecenderungan orang memberikan nilai yang berarti pernyataan setuju bahwa desa yang dideskripsikan tersebut merupakan DW. Pendekatan seperti ini akan membantu kita dan masyarakat untuk memahami konsep-konsep abstrak yang melibatkan aspek kognitif yang terdapat di dalam pemikiran penutur sesuai dengan latar belakang dan budayanya masing-masing.

Dalam memaknai DW, masyarakat melakukannya secara aktif terhadap realitas yang bersifat objektif dan subjektif melalui sosialisasi diri. Ini sesuai dengan asumsi 
teori fenomenologi dari Schutz (1967:7). Meskipun demikian, pada dasarnya tindakan komunikatif bersifat sukarela, yaitu memandang komunikator sebagai pembuat pilihan. Tidak berarti seseorang memiliki pilihan bebas. Lingkungan sosial akan membatasi apa yang dapat dan sudah dilakukan, meskipun dalam banyak kondisi, ada banyak elemen tertentu yang bisa dipilih.

Pada dasarnya pengetahuan bukanlah suatu yang ditemukan secara objektif. Pengetahuan merupakan produk sosial, yang diturunkan dari interaksi dalam kelompok-kelompok sosial. Bahasa kemudian membentuk realitas dan pengertian menentuan apa yang kita ketahui.

Pengetahuan bersifat kontekstual, yaitu pengertian terhadap peristiwa selalu merupakan produk dari interaksi pada waktu dan tempat tertentu, pada lingkungan sosial budaya tertentu. Pemahamanan tentang peristiwa akan berubah sesuai dengan berjalannya waktu.

Hal ini sesuai dengan salah satu asumsi pada teori interaksi simbolik Blumer (1986:2) yang menyatakan bahwa makna diberikan oleh manusia sebagai hasil interaksi dengan sesamanya. Dengan demikian, makna tidak inherent, tidak terlekat pada benda atau fenomenanya, tetapi tergantung pemaknaan dari orang-orang yang terlibat dalam interaksi tersebut.

Fenomena masyarakat dalam memaknai istilah DW dapat dianggap bagian dari apa yang disebut dalam teori tindakan sosial dari Weber (Mulyana, 2008:60). Perilaku masyarakat dalam memberi makna istilah DW secara subjektif dan unik ditujukan untuk mempengaruhi atau berorientasi pada perilaku orang lain.

Masyarakat yang memberikan makna istilah DW dapat disebut sebagai aktor yang melakukan tindakan sosial. Pada aktor tersebut juga memiliki historisitas dan dapat dilihat dalam bentuk yang alami. Mereka memaknai istilah DW dari luar atau dari arus utama pengalaman, yaitu melalui proses tipifikasi. Dalam hal ini termasuk membentuk penggolongan atau klasifikasi dari pengalaman yang ada. Hubunganhubungan makna diorganisir secara bersama-sama melalui proses tipifikasi ke dalam "kumpulan pengetahuan" (stock of knowledge), yang merupakan kegunaan-kegunaan praktis dari dunia itu sendiri.

Selain itu, yang mesti diingat bahwa para responden kuesioner juga merupakan individu-individu yang dalam memaknai istilah DW sangat tergantung pada kompleksitas kognitif yang ada pada diri masing-masing. Bagaimanapun miripnya tingkat pendidikan, setiap orang berpikir dengan tingkat kecerdasan yang berbedabeda, tergantung masalah dan topiknya.

Responden yang memiliki kecerdasan kognitif lebih bagus dapat memilihat lebih banyak perbedaan daripada mereka yang memiliki kecerdasan kognitif biasa saja. Perbedaan mempersepsikan istilah DW bukanlah sesuatu yang diturunkan atau bersifat alami, tetapi ditentukan oleh seperangkat pengetahuan yang ada dalam sistem kognitif individu. Meskipun terdapat perbedaan, tentu hal ini tidak sangat ekstrim karena istilah DW merupakan istilah yang populer dan berbagai kalangan sepertinya mengenal istilah ini. Populernya istilah DW ini tidak lepas dari gencarnya pemerintah dalam melakukan sosialisasi dan pengembangan DW-DW di seluruh Indonesia. Selain itu, karena pada praktiknya pembukaan dan pengembangan DW selalu melibatkan masyarakat setempat berkaitan dengan program pemberdayaan masyarakat. 
Terbukti dalam pemberian makna DW, variabel bebas yang menjadi latar belakang responden, yaitu umur, jenis kelamin, latar belakang pendidikan dan latar belakang pekerjaan, tidak banyak berpengaruh dalam mendefinisikan istilah DW. Hal ini dapat diduga karena begitu gencarnya promosi pemerintah terhadap program DW sejak tahun 2000 dan hingga sekarang pun terus dilakukan pembukaan DW-DW di daerah-daerah yang potensial pariwisatanya. Hal ini dapat diduga sebagai pemicu lebih pahamnya masyarakat terhadap definisi DW. Terlebih ketika kuesioner ini disampaikan kepada mereka yang berpendidikan tinggi (lebih dari SMU) dan dalam usia produktif (25-65 tahun). Artinya, secara umum dengan pendidikan tersebut mereka setidaknya kenal dengan istilah DW dan karena dalam masa usia produktif, mereka juga lebih memungkinkan untuk mengakses informasi dan perkembangan yang ada di lapangan berkaitan dengan adanya DW.

\section{KESIMPULAN}

Hasil analisis data menunjukkan bahwa masyarakat memiliki beragam persepsi tentang DW sesuai dengan social setting atau latar belakang budayanya. Keragaman interpretasi terhadap DW oleh masyarakat ternyata tetap mengacu pada hipotesis yang telah diajukan. Pengertian istilah DW tersebut tidak terlepas dari variabelvariabel yang telah ditentukan dalam hipotesis.

Jadi, penelitian ini menyimpulkan bahwa makna dari istilah DW melibatkan empat variabel utama sebagai penentu, yaitu (1) keindahan alam, (2) keterampilan penduduk, (3) kebudayaan, dan (4) kedatangan orang. Artinya suatu desa dapat disebut dengan DW kalau memiliki keindahan alam, ada keterampilan penduduk yang bisa dijual, memiliki kebudayaan yang khas, dan ada kedatangan orang ke desa tersebut. Semakin banyak variabel yang terdapat di suatu desa, maka semakin besar desa tersebut termasuk dalam definisi DW menurut penelitian ini.

Beberapa desa yang mengandung tiga dari keempat variabel tersebut, dianggap sebagai DW oleh sebagian masyarakat, meskipun skor rata-ratanya rendah. Dengan demikian, penyusunan definisi DW dengan mengikuti kajian semantic prototipe dengan memperhatikan fenomena yang ada di masyarakat, akan membantu para penyusun kamus bahasa Indonesia untuk mendefinisikan DW secara tepat dan sesuai dengan keadaan di lapangan. Prinsip-prinsip pendefinisian istilah DW ini juga akan dapat membantu pihak-pihak lain yang berkaitan untuk memperkaya definisi-definisi istilah yang abstrak dan bertingkat.

\section{DAFTAR PUSTAKA}

Ahimsa-Putra, Shri Heddy. 2009. "Fenomenologi Agama: Pendekatan Fenomenologi untuk Memahami Agama" dalam Jurnal Penelitian Walisongo. Vol. XVII, No. 2, Nopember 2009. ISSN 0852 7172. Semarang: Pusat Penelitian (Puslit) IAIN Walisongo Semarang.

Blumer, Herbert. 1986. Symbolic Interactionism: Perspective and Method. London: University of California Press Barkeley Los Angeles. 
Coleman, Linda \& Paul Kay. 1981. Prototype Semantics: The English Word Lie. Language 57(1). 6-44.

Cresswell, John W. 1994. Qualitative Inquiry and Research Design, Choosing Among Five Tradition. The United State of America:Sage Publications Inc.

Fillmore, Charles. 1975. An Alternative to Checklist Theories of Meaning. Proceedings of the $1^{\text {st }}$ Annual Meeting. Berkeley Linguistics Society, 123-31.

Kluckhohn, C. 1962. Universal Categories of Culture. In S. Tax (Ed.). Anthropology Today Selection (pp 304-320). Chicago: University of Chicago Press. First Published 1953.

Kuswarno, Engkus. 2009. Metodologi Penelitian Komunikasi, Fenomenologi, Konsepsi, Pedoman dan Contoh Penelitian. Bandung: Widya Padjadjaran.

Langacker, Ronald W. 2008. Cognitive Grammar: A Basic Introduction. New York: Oxford University Press.

Mulyana, Deddy. 2008. Metodologi Penelitian Kualitatif. Paradigma Baru Ilmu Komunikasi dan Ilmu Sosial Lainnya. Bandung: Rosda.

Nida, Eugene, A. 1971 (Reprint 1975). "Semantic Components in Translation Theory" in Application of Linguistics. Selected Papers of the Second International Congress of Applied Linguistics, Cambridge 1969. Cambridge: University Press.

Nuryanti, Wiendu. 1993. "Concept, Perspective and Challenges" Makalah bagian dari Laporan Konferensi Internasional mengenai Pariwisata Budaya. Yogyakarta: Gadjah Mada University Press.

Schutz, Alfred. 1967. The Phenomenology of the Social World. Evanston: Illinois Northwstern University Press.

Tim Penyusun. 2007. Kamus Besar Bahasa Indonesia. Jakarta: Balai Pustaka.

www.bisnis.com dalam artikel “2019, Indonesia Ditargetkan Punya 2.000 Desa Wisata" oleh Yanita Patriela. Diakses Desember 2019. 